\title{
Multi-stage Series Heat Pump Drying System with Dehumidification Simulation and Experiment Verification
}

\author{
Chao Wang ${ }^{1,2, a}$, Zhentao Zhang ${ }^{1,3, b,{ }^{*}}$ Luwei Yang ${ }^{1,3, c}$ and Juan Wei ${ }^{1,3}$ \\ ${ }^{1}$ Technical Institute of Physics and Chemistry, Chinese Academy of Sciences, Beijing 100190 \\ ${ }^{2}$ University of Chinese Academy of Sciences, Beijing 100049 \\ ${ }^{3}$ Beijing Key Laboratory of Thermal Science and Technology, Beijing 100190 \\ aUCAS_WANG@163.com, bzzth1@163.com, 'Iwyang2002@mail.ipc.ac.cn
}

${ }^{*}$ Corresponding author

\begin{abstract}
Keywords: Heat pump; Drying; Dehumidification; Multi-stage; SMER
Abstract. A multi-stage series heat pump drying system with dehumidification is proposed to meet the demand of corn drying in Northeast China. The mathematical model of the system is developed in EES (Engineering Equation Solver). After building the model, the system's performance under stable conditions is simulated. The result shows that a 5-stage system has a dehumidification rate of 400 $\mathrm{kg} \cdot \mathrm{h}^{-1}$ and a SMER (specific moisture extraction rate) of $4 \mathrm{~kg} / \mathrm{kW} \cdot \mathrm{h}$. The primary air flowrate, air inlet temperature and air inlet relative humidity are the main parameters influencing the system performance. The dehumidification rate and SMER of the system have positive correlations with them. The air inlet temperature and air inlet relative humidity have more significant influence. An experiment of 4-stage system is conducted and the result is consistent with simulation. Currently, coal is the main energy source for drying corn in Northeast China, not only wasting a lot of energy, but also causing serious pollution. Compared with burning coal, the proposed system has great potential for energy saving and environmental protection.
\end{abstract}

\section{Introduction}

Grain drying is one of the most energy-consuming procedure in food industry in China[1]. In many industrial drying processes, a large fraction of energy is wasted[2]. Currently, coal is the main energy source for drying corn in Northeast China, not only wasting a lot of energy, but also causing serious pollution. According to the work of DI Kun[3], the energy consumption for corn drying using coal reaches $7535 \sim 8370 \mathrm{~kJ} / \mathrm{kgH}_{2} \mathrm{O}$. Besides, during the combustion of coal, a large number of harmful gases like $\mathrm{CO}, \mathrm{SO}_{2}$ and $\mathrm{NO}_{\mathrm{x}}$ emit into the atmosphere, causing serious smog, acid rain, and toxic air pollution.

Numerous work is done on the heat pump drying systems[4, 5]. Heat pump dehumidifier dryers offer several advantages over conventional hot-air dryers for the drying of food products, including higher energy efficiency, better product quality, and the ability to operate independently of outside ambient weather conditions[6]. According to Claussen IC[7], the energy saving potential and the ability to control drying temperature and air humidity are the main advantages of using heat pump technology. Strommen et al.[8] found that heat pump dryers consume 60-80\% less energy than conventional dryers operating at the same temperature.

EES (Engineering Equation Solver) is a general equation-solving program that can numerically solve thousands of coupled non-linear algebraic and differential equations [9]. This paper uses EES to build the system's mathematical model and study the system's performance under different parameters.

For the drying process of corn in Northeast China, the system is running for about 3 months without stopping, the working conditions are very stable. So this article focuses on the steady conditions.

In this study, a 5-stage heat pump dryer with dehumidification is proposed. A simulation model for the steady condition of the system is developed. An experiment of 4-stage system is conducted and compared with the simulation results. 


\section{Proposed system}

A schematic view of the proposed system is shown in Fig. 1. Points 1 to 12 refer to the different positions in system. The air at point 1 is from corn drying tower, it is close to saturated air and it has a temperature of $35^{\circ} \mathrm{C}$. As the moist air passes through the evaporators, it is cooled and dehumidified to point 6 . Between point 6 and point 7 , there is a vent for bypassed air. The properties of bypassed air is the same as inlet air at point 1 . The flowrate of bypassed air can be controlled by the damper installed at the vent. After air at point 6 mixes with bypassed air, the total air flow is heated by 5 condensers and reaches point 12 , which is the hot air to be delivered into the corn drying tower.

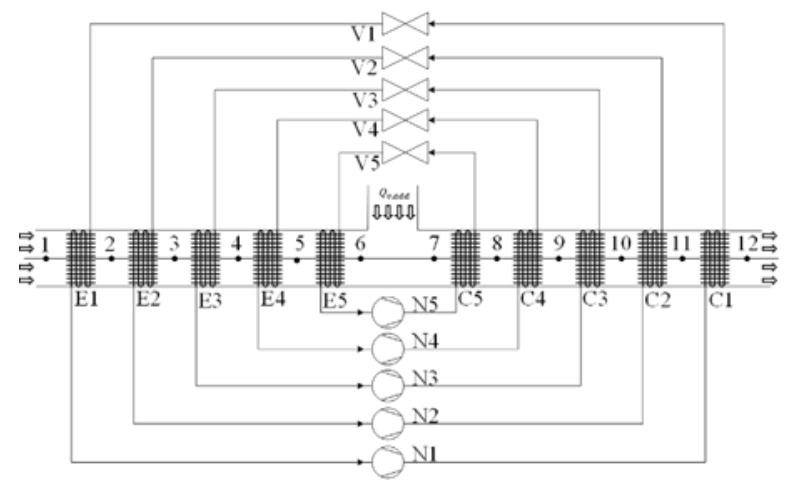

Fig. 1 Schematic view of the proposed system.

In this system there are three different air flowrates: the main air flowrate refers to the air flowrate at point 1; the bypassed air flowrate refers to the air flowrate added between point 6 and point 7; the total air flowrate refers to the air flowrate at point 12 .

There are 5 heat pump units in this system. In Fig. 1 E represents evaporator, $\mathrm{C}$ represents condenser, $\mathrm{V}$ represents expansion valve, $\mathrm{N}$ represents compressor. The numbers next to these letters are the serial number of heat pump units.

There is both sensible and latent heat exchanging in evaporator, but only sensible heat exchanging in condenser. The latent heat of water is very huge, about $2453 \mathrm{~kJ} / \mathrm{kg}$ at $20^{\circ} \mathrm{C}$ and $1 \mathrm{~atm}$. When the inlet air has a high relative humidity, the air temperature in the condenser side will increase rapidly, causing the first or the first and second heat pump system self-protected due to high discharge pressure. The bypassed air is introduced to ensure the normal operation of heat pump units. Bypassed air flowrate can be adjusted to get the required air outlet temperature.

\section{System model}

All 5 heat pump units use R134a as refrigerant, and the compressors' theoretical displacement $V_{d}$ is $92.4 \mathrm{~m}^{3} \cdot \mathrm{h}^{-1}$. The main assumptions for the simulation model are as follows:

1. The superheat at evaporator outlet is $5^{\circ} \mathrm{C}$, the subcooling at condenser outlet is $5^{\circ} \mathrm{C}$;

2. The volumetric and isentropic efficiency of compressor is 0.9 ;

3. The evaporation temperature is $6^{\circ} \mathrm{C}$ greater than the air temperature at evaporator outlet, the condensation temperature is $3^{\circ} \mathrm{C}$ greater than the air temperature at condenser outlet;

4. If refrigerant side cooling capacity is sufficient, the moist air release its sensible heat first.

The simulation of system mainly concerns about the energy balance between the refrigerant and the moist air. Assumption 4 intends to simplify the calculation. In real situation the air inlet relative humidity is above $60 \%$, the moist air at point 2 is nearly saturated. So assumption 4 will not introduce extra error.

For $i$ th heat pump unit, the compressor is $\mathrm{N}_{\mathrm{i}}$, the evaporator is $\mathrm{E}_{\mathrm{i}}$, the condenser is $\mathrm{C}_{\mathrm{i}}$, the expansion valve is $\mathrm{V}_{\mathrm{i}}$, the evaporation temperature of refrigerant is $T_{e, i}$, the condensation temperature of refrigerant is $T_{c, i}$, the moist air temperature at evaporator inlet is $T_{i}$, the moist air temperature at evaporator outlet is $T_{i+1}$, the moist air temperature at condenser inlet is $T_{12-i}$, the moist air temperature at condenser outlet is $T_{13-i}$. 
The moist air side calculation is based on the mass flowrate of dry air, at point 1 the main dry air mass flowrate $Q_{m, 1}$ is determined by:

$$
Q_{m, 1}=\frac{Q_{v, 1} \rho_{1}}{1+\omega_{1}}
$$

The bypassed dry air mass flowrate can be determined by the same method:

$$
Q_{m, \text { add }}=\frac{Q_{v, \text { add }} \rho_{\text {add }}}{1+\omega_{\text {add }}} .
$$

For the $i$ th heat pump unit, based on the conservation of dry air mass flowrate, we can obtain the following relationship:

$$
\begin{aligned}
& Q_{m, i}=Q_{m, i+1} . \\
& Q_{m, 12-i}=Q_{m, 13-i} .
\end{aligned}
$$

According to assumption 4, for the $i$ th heat pump unit:

$$
\begin{aligned}
& T_{e, i}=T_{i+1}+6^{\circ} \mathrm{C} . \\
& T_{c, i}=T_{13-i}+3^{\circ} \mathrm{C} .
\end{aligned}
$$

The calculation focus on the energy balance between the refrigerant and the moist air. Two sides are connected through the energy balance of heat transfer and Eq. 5 Eq. 6.

Refrigerant side. A pressure-enthalpy diagram of a basic heat pump cycle using R134a is shown in Fig. 2 . $1 \rightarrow 2$ is the compression process, $2 \rightarrow 4$ is the process in condenser, $4 \rightarrow 5$ is the process through the expansion valve, $5 \rightarrow 1$ is the process in evaporator.

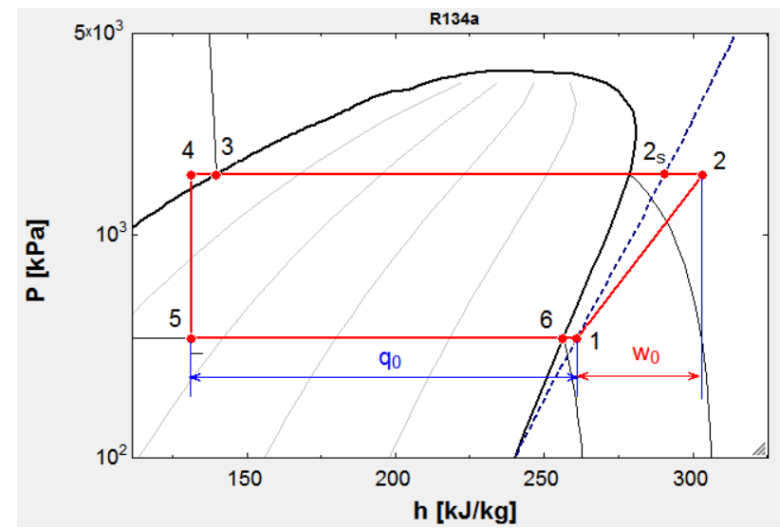

Fig. 2 Pressure-enthalpy diagram of heat pump using R134a.

The mass flowrate of refrigerant can be calculated as:

$$
\dot{m}_{r}=\eta_{v} V_{D} \rho_{r, 1}
$$

Where $\eta_{v}$ is volumetric efficiency, $\rho_{r, 1}$ is the density of suction vapor.

When the mass flowrate of refrigerant is known, the work delivered to vapor refrigerant $W_{i}$, the capacity of a evaporator $Q_{e}$, the capacity of a condenser $Q_{i}$ can be calculated as: 


$$
\begin{aligned}
& W_{i}(i)=\frac{\dot{m}_{r}\left(h_{r, 2 s}-h_{2}\right)}{\eta_{s}} . \\
& Q_{e}(i)=\dot{m}_{r}\left(h_{r, 1}-h_{r, 5}\right) . \\
& Q_{c}(i)=\dot{m}_{r}\left(h_{r, 2}-h_{r, 4}\right) .
\end{aligned}
$$

Assume motor efficiency $\eta_{m o}$ and mechanical efficiency $\eta_{m}$ all equal to 0.9 . The power input to motor is:

$$
W_{c}(i)=\frac{W_{i}(i)}{\eta_{m} \eta_{m o}} .
$$

The coefficient of performance for heating is:

$$
\operatorname{COP}_{h}(i)=\frac{Q_{c}(i)}{W_{c}(i)}
$$

The $i$ in Eq. 8 Eq. 12 represents the $i$ th heat pump unit. Each heat pump unit is calculated using corresponding $p$ - $h$ diagram.

Moist air side. When moist air passes through evaporator both moisture and sensible heat is removed. For the $i$ th heat pump:

$$
\left(1+\omega_{i}\right) Q_{m, i} h_{i}=\left(1+\omega_{i+1}\right) Q_{m, i+1} h_{i+1}+\left(\omega_{i}-\omega_{i+1}\right) Q_{m, i} h_{\text {water }, T=T_{i+1}}+Q_{e}(i)
$$

The dehumidification rate of evaporator:

$$
\dot{m}_{\text {water }}(i)=Q_{m, i+1} \omega_{i+1}-Q_{m, i} \omega_{i} .
$$

For the condenser side, there is only sensible heat change in moist air, so humidity ratio is a constant through condenser.

$$
\begin{aligned}
& \left(1+\omega_{13-i}\right) Q_{m, 13-i} h_{13-i}=\left(1+\omega_{12-i}\right) Q_{m, 12-i} h_{12-i}+Q_{c}(i) . \\
& \omega_{12-i}=\omega_{13-i} .
\end{aligned}
$$

Between point 6 and point 7 there is a mixing process of main air flow and bypassed air flow. Assuming no water is condensed during the mixing process, the properties of moist air at point 7 can be got based on mass and energy balance:

$$
\begin{aligned}
& Q_{m, 7}=Q_{m, 6}+Q_{m, \text { add }} . \\
& \left(1+\omega_{7}\right) Q_{m, 7} h_{7}=\left(1+\omega_{6}\right) Q_{m, 6} h_{6}+\left(1+\omega_{\text {add }}\right) Q_{m, \text { add }} h_{\text {add }} . \\
& \omega_{7} Q_{m, 7}=\omega_{6} Q_{m, 6}+\omega_{\text {add }} Q_{m, \text { add }} .
\end{aligned}
$$

If there is water condensed during the mixing process, the water will absorb heat from condenser and then evaporate. So, no extra heat is introduced into system during this condensing and evaporating process. Eq. $17 \sim$ Eq. 19 can still be used for calculation.

Parameters for evaluating the system. This system is intended for corn drying in Northeast China, the dehumidification rate $\dot{m}_{\text {ware }}$ and SMER is chosen to evaluate the performance of this system. They can be calculated as: 


$$
\begin{aligned}
& \dot{m}_{\text {water }}=\sum_{i=1}^{5} \dot{m}_{\text {water }}(i) . \\
& S M E R=\frac{\dot{m}_{\text {water }}}{\sum_{i=1}^{5} W_{c}(i)} .
\end{aligned}
$$

The system's total air flowrate is also an important parameter in system design, it is the sum of main air flowrate and bypassed air flowrate:

$$
Q_{v, \text { total }}=Q_{v, 1}+Q_{v, \text { add }} .
$$

\section{Results}

Simulation results of 5-stage system. The chosen operation condition is: $Q_{v, 1}=20000 \mathrm{~m}^{3} \cdot \mathrm{h}^{-1}$, $T_{1}=35^{\circ} \mathrm{C}, R h_{1}=90 \%$, the required air outlet temperature is $75^{\circ} \mathrm{C}$. Under this condition, a 5-stage system is simulated using model developed above. The results are in Fig. 3.

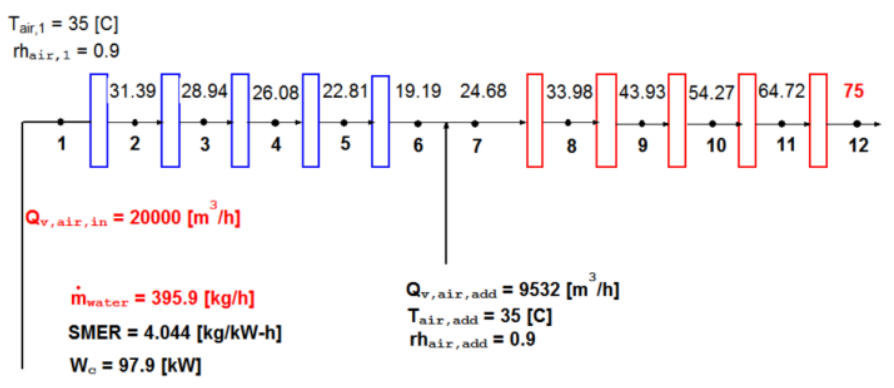

Fig. 3 Simulation results of a 5-stage system.

As can be seen from Fig. 3, the system has a dehumidification rate of $395.9 \mathrm{~kg} \cdot \mathrm{h}^{-1}$ and a SMER of $4.0 \mathrm{~kg} / \mathrm{kW} \cdot \mathrm{h}$. The total input power of compressors is $97.9 \mathrm{~kW}$. The inlet air temperature is $35^{\circ} \mathrm{C}$ and is cooled to $19.19^{\circ} \mathrm{C}$ after passing through 5 evaporators. In order to obtain a $75^{\circ} \mathrm{C}$ outlet air temperature, $9532 \mathrm{~m}^{3} \cdot \mathrm{h}^{-1}$ bypassed air is needed. Thus the total air flowrate is $29532 \mathrm{~m}^{3} \cdot \mathrm{h}^{-1}$.

If the efficiency from coal to electricity is $40 \%$, compared with literature [2], the energy consumption of proposed system is only $28 \%$ of traditional system using coal as energy source.

Table. 1 lists the operation parameters of 5 heat pump units which have very different operation conditions. The heat pump unit located inner has a higher COP, so it is more energy efficient.

Table. 1 Operation parameters of 5 heat pump units

\begin{tabular}{|c|c|c|c|c|}
\hline $\begin{array}{c}\text { Heat pump } \\
\text { unit number }\end{array}$ & $\begin{array}{c}\text { Evaporation tempera- } \\
\text { ture } \\
{\left[{ }^{\circ} \mathrm{C}\right]}\end{array}$ & $\begin{array}{c}\text { Condensation temper- } \\
\text { ature } \\
{\left[{ }^{\circ} \mathrm{C}\right]}\end{array}$ & $\begin{array}{c}\text { Power input } \\
{[\mathrm{kW}]}\end{array}$ & COP of heating \\
\hline 1 & 23.39 & 80.00 & 28.16 & 3.3 \\
\hline 2 & 20.94 & 69.72 & 23.62 & 4.0 \\
\hline 3 & 18.08 & 59.27 & 19.18 & 4.9 \\
\hline 4 & 14.81 & 48.93 & 15.07 & 6.0 \\
\hline 5 & 11.19 & 40.00 & 11.86 & 7.2 \\
\hline
\end{tabular}

Analysis of system influence factors. The main air flowrate $Q_{v, 1}$, air inlet temperature $T_{1}$, air inlet relative humidity $R h_{1}$ are the main parameters influencing the performance of proposed system.

All the following analyses are based on the 5-stage system mentioned in section 1 and use the model built in section 3 . 
The influence of main air flowrate. To study the influence of main air flowrate, air inlet temperature $T_{1}$ is kept $35^{\circ} \mathrm{C}$, air inlet relative humidity $R h_{1}$ is kept $90 \%$. The air outlet temperature remains $75^{\circ} \mathrm{C}$. The main air flowrate is varied from $15000 \mathrm{~m}^{3} \cdot \mathrm{h}^{-1}$ to $25000 \mathrm{~m}^{3} \cdot \mathrm{h}^{-1}$.

(a)

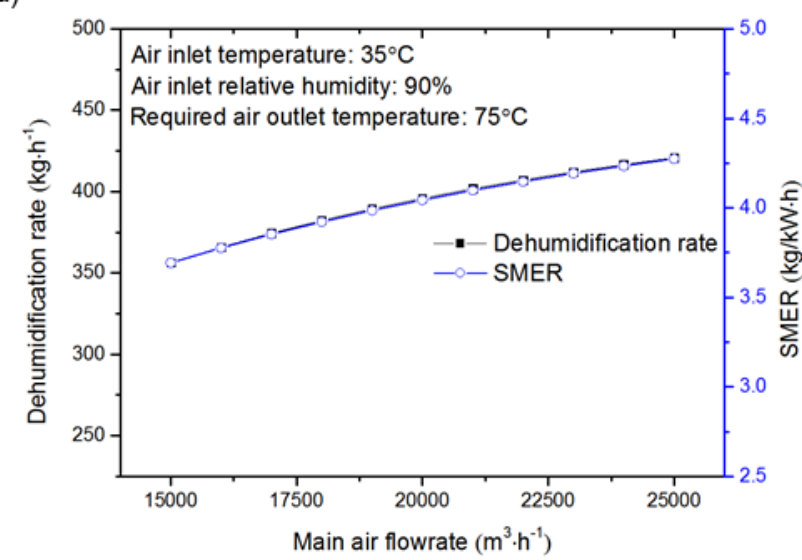

(a)Dehumidification rate and SMER. (b)

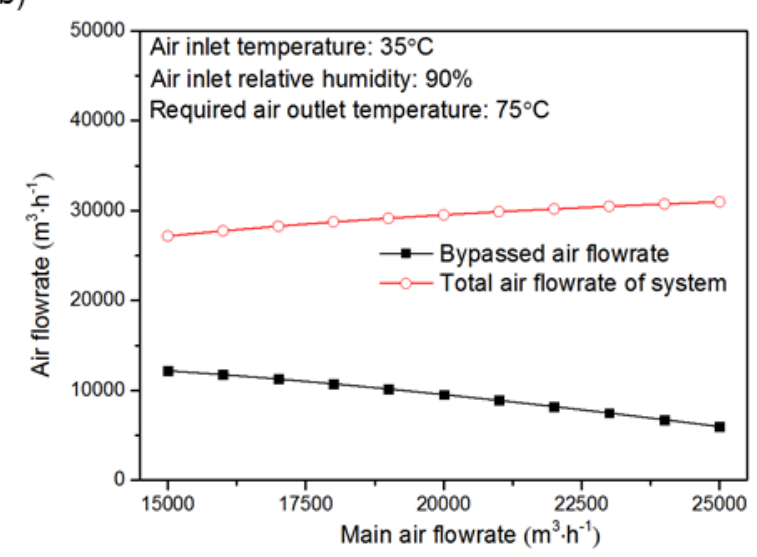

(b) Bypassed and total air flowrate.

Fig. 4 Performance of system when varying the main air flowrate.

As is shown in Fig. 4 (a), the dehumidification rate and SMER increase with the main air flowrate. Since the inlet and outlet temperature is kept constant, the operation conditions of heat pump units are almost unchanged. Thus the trend of dehumidification rate is consistent with the trend of SMER.

Fig. 4 (b) indicates that the total air flowrate increases slowly with the main air flowrate.

The influence of air inlet temperature. To study the influence of air inlet temperature, main air flowrate $Q_{v, 1}$ is kept $20000 \mathrm{~m}^{3} \cdot \mathrm{h}^{-1}$, air inlet relative humidity $R h_{1}$ is kept $90 \%$. The air outlet temperature remains $75^{\circ} \mathrm{C}$. The air inlet temperature is varied from $30^{\circ} \mathrm{C}$ to $40^{\circ} \mathrm{C}$.

(a)

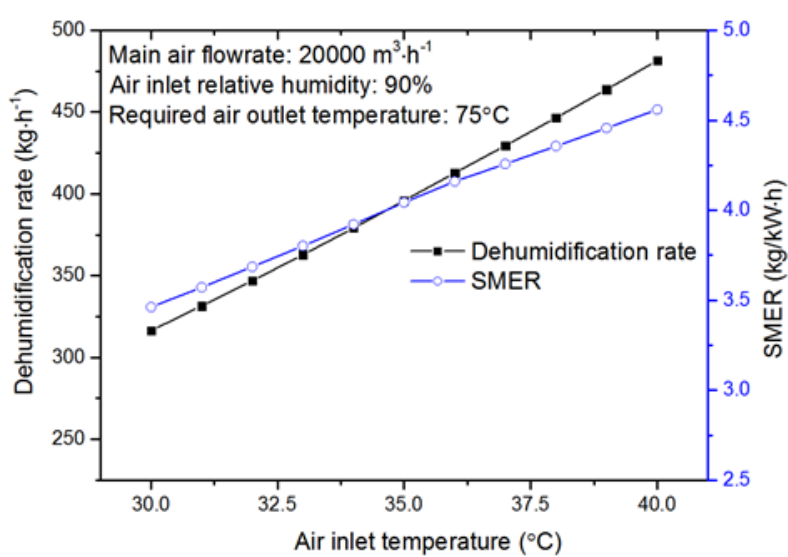

(a)Dehumidification rate and SMER. (b)

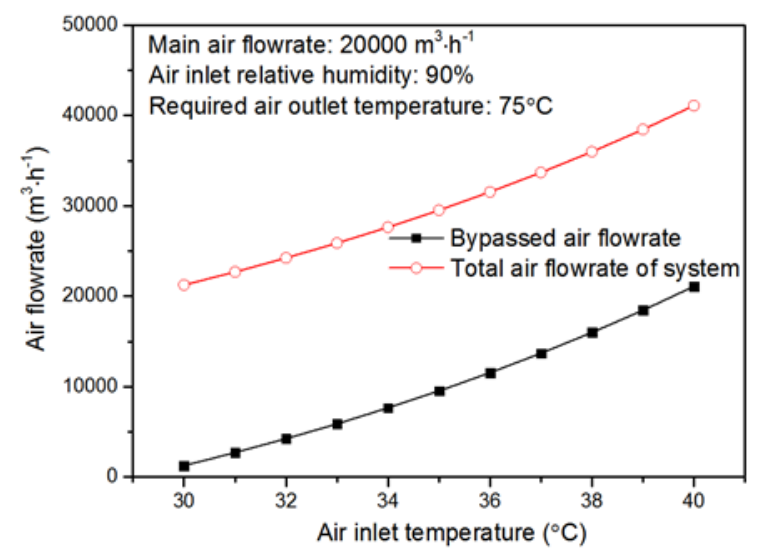

(b) Bypassed and total air flowrate.

Fig. 5 Performance of system when varying the air inlet temperature.

As is shown in Fig. 5 (a), the dehumidification rate and SMER increase significantly with the air inlet temperature. With other parameters unchanged, when the air inlet temperature varies from $30^{\circ} \mathrm{C}$ to $40^{\circ} \mathrm{C}$, the dehumidification rate increases from $320 \mathrm{~kg} \cdot \mathrm{h}^{-1}$ to $475 \mathrm{~kg} \cdot \mathrm{h}^{-1}$, the SMER increases from $3.5 \mathrm{~kg} / \mathrm{kW} \cdot \mathrm{h}$ to $4.5 \mathrm{~kg} / \mathrm{kW} \cdot \mathrm{h}$.

Fig. 5 (b) indicates that the air inlet temperature also has a significant influence on the amount of required bypassed air. So when designing a new system, air inlet temperature must be taken into account to determine the total air flowrate of the system. 
The influence of air inlet relative humidity. To study the influence of air inlet relative humidity, main air flowrate $Q_{v, 1}$ is kept $20000 \mathrm{~m}^{3} \cdot \mathrm{h}^{-1}$, air inlet temperature $T_{1}$ is kept $35^{\circ} \mathrm{C}$. The air outlet temperature remains $75^{\circ} \mathrm{C}$. The air inlet relative humidity is varied from $60 \%$ to $100 \%$.

(a)

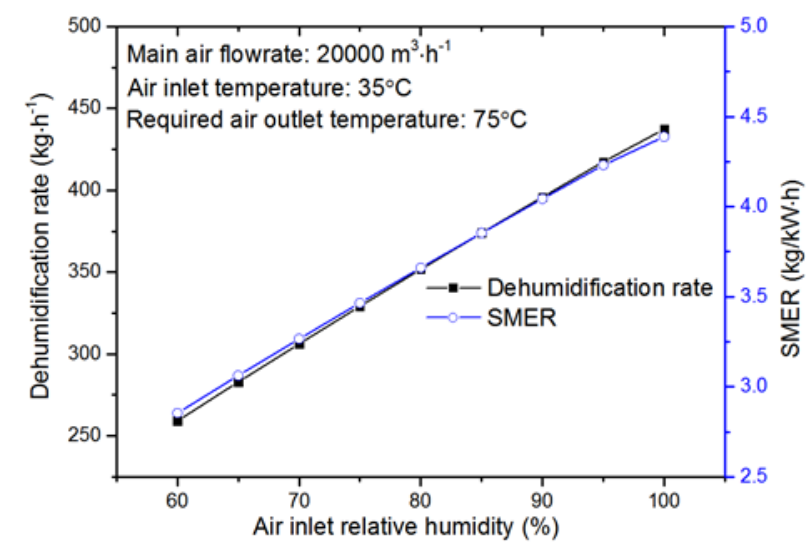

(a)Dehumidification rate and SMER. (b)

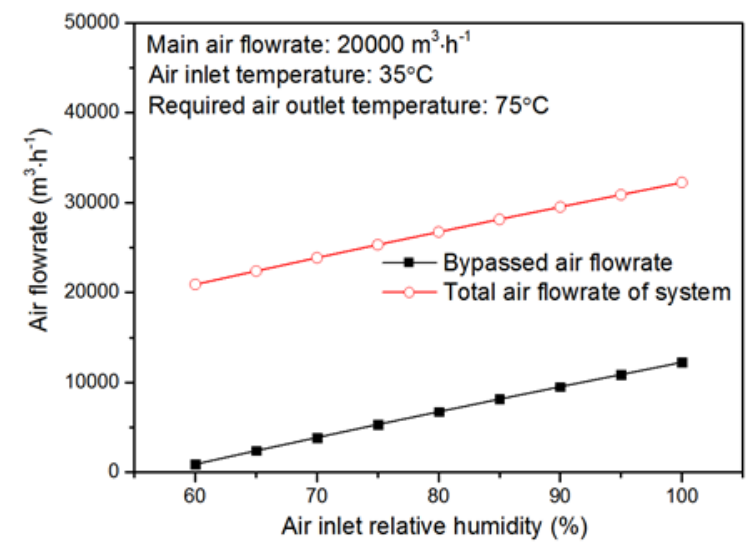

(b) Bypassed and total air flowrate.

Fig. 6 Performance of system when varying the inlet relative humidity.

As is shown in Fig. 6 (a), the air inlet relative humidity also has significant influence on the system's performance. With other parameters unchanged, if the air inlet relative humidity varies from $60 \%$ to $100 \%$, the dehumidification rate increases from $260 \mathrm{~kg} \cdot \mathrm{h}^{-1}$ to $445 \mathrm{~kg} \cdot \mathrm{h}^{-1}$, the SMER increases from $2.9 \mathrm{~kg} / \mathrm{kW} \cdot \mathrm{h}$ to $4.4 \mathrm{~kg} / \mathrm{kW} \cdot \mathrm{h}$.

As is shown in Fig. 6 (b), air inlet relative humidity also has a significant influence on the amount of required bypassed air. When the air inlet relative humidity is $60 \%$, no bypassed air is needed. When the air inlet relative humidity is $100 \%$, nearly $12500 \mathrm{~m}^{3} \cdot \mathrm{h}^{-1}$ bypassed air is needed to ensure the air outlet temperature is $75^{\circ} \mathrm{C}$.

\section{Experiment verification}

(a)

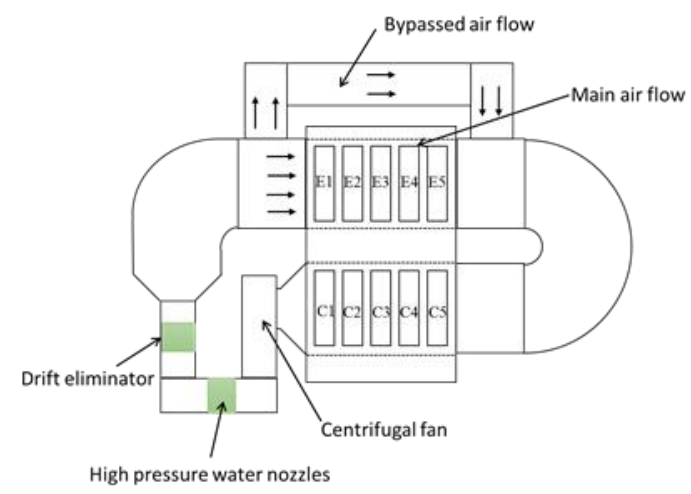

(a)Schematic view. (b)

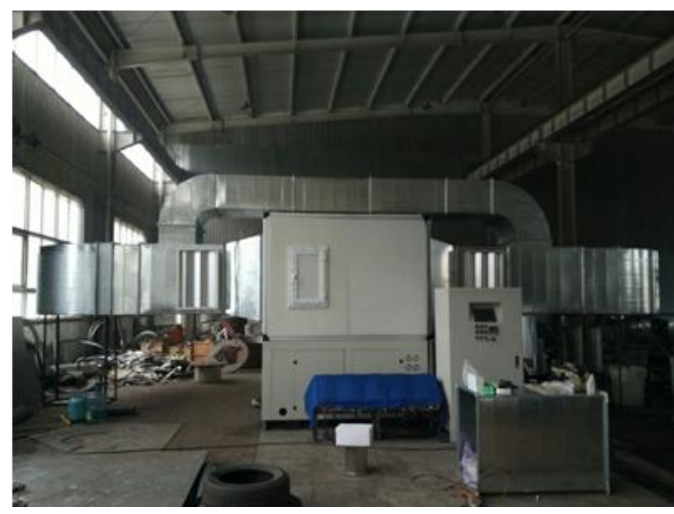

(b) Prototype.

Fig. 7 Experiment device.

A schematic view of experiment device is shown in Fig. 7 (a). The experiment prototype shown in Fig. 7 (b) is connected by ducts. After the centrifugal fan a row of high pressure water nozzles are installed to cool and humidify the hot air from the outlet of condenser. This is intended to simulate the drying process. In the air stream, large water droplets are intercepted by the drift eliminator installed after nozzles. Under the evaporators there is a water pan which can hold water to measure the dehumidification rate.

Restricted by experiment conditions, the total air flowrate is $20000 \mathrm{~m}^{3} \cdot \mathrm{h}^{-1}$, including main air flowrate of $13000 \mathrm{~m}^{3} \cdot \mathrm{h}^{-1}$ and bypassed air flowrate of $7000 \mathrm{~m}^{3} \cdot \mathrm{h}^{-1}$. Since the total air flowrate is small, only 4 heat pump units is started. 
In this system compressors are connected with frequency converters. During the experiments all compressors are running at $40 \mathrm{~Hz}$. In simulation the displacement of compressor is calculated as $80 \%$ of the theoretical displacement.

When the experiment is stable, the inlet air temperature is $36.3^{\circ} \mathrm{C}$, relative humidity is $80.86 \%$. The simulation results of 4-stage system under this air inlet condition is shown in Fig. 8.

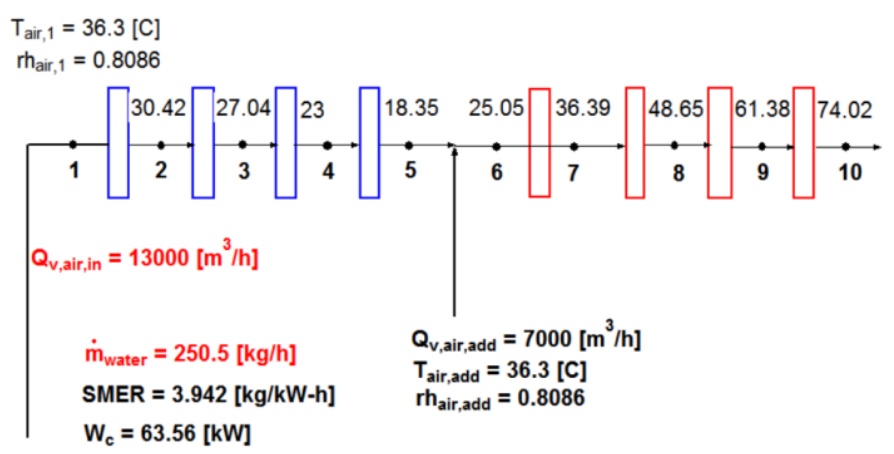

Fig. 8 Simulation results of a 4-stage system.

Comparison between simulation and experiment results is shown in Fig. 9. The simulation results has a good agreement with the experiment results. Simulation model is efficient and effective.

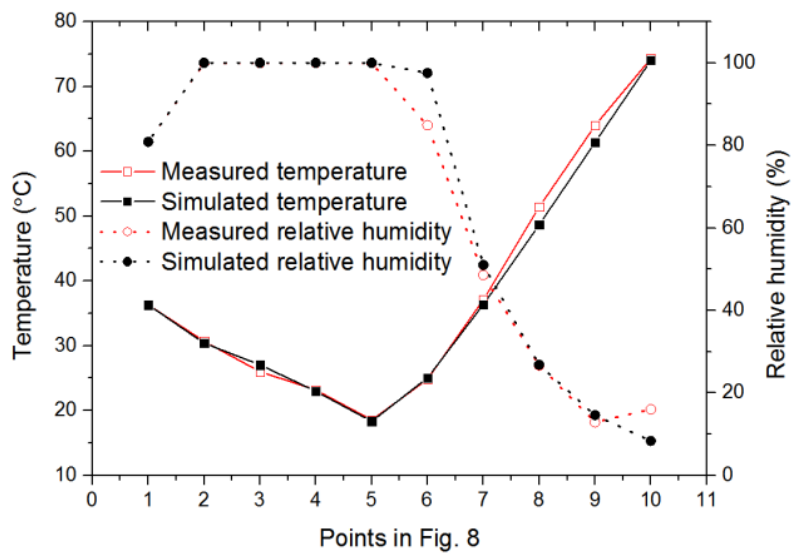

Fig. 9 Comparison between simulation and experiment results.

During the experiment the measured dehumidification rate is $280 \mathrm{~kg} \cdot \mathrm{h}^{-1}$. Although drift eliminators are installed to intercept large water droplets, some water droplets still flying into evaporator side. Thus the measured dehumidification rate is higher than actual situation.

\section{Conclusions}

The simulation results show that a 5-stage system have a dehumidification rate of $400 \mathrm{~kg} \cdot \mathrm{h}^{-1}$ and a SMER of $4 \mathrm{~kg} / \mathrm{kW} \cdot \mathrm{h}$. Its energy consumption is only $28 \%$ of the system using coal as energy source.

Increasing main air flowrate, air inlet temperature or air inlet relative humidity will all lead to the increase of dehumidification rate and SMER of system. Among the three parameters, air inlet temperature and air inlet relative humidity have more significant influences. The proposed system is more energy-saving with high air inlet temperature and relative humidity.

Since main air flowrate, air inlet temperature and air inlet relative humidity have influences on the required bypass air flowrate, when designing a new system, proper total air flowrate must be chosen.

Both simulation and experiment work is carried out for a 4-stage system. The simulation result is consistent with experiment.

With great potential for energy saving and environmental protection, the proposed system is expected to replace the system using coal in Northeast China. 


\section{Acknowledgements}

This work was financially supported by a grant from the National High Technology Research and Development Program of China (863 Program, China) (grant No. 2012AA10A510).

\section{Nomenclature}

\begin{tabular}{|c|c|}
\hline $\mathrm{C}$ & condenser \\
\hline $\mathrm{E}$ & evaporator \\
\hline$\dot{m}$ & $\begin{array}{l}\text { mass flowrate of } \\
\text { refrigerant, } \mathrm{kg} \cdot \mathrm{h}^{-1}\end{array}$ \\
\hline$h$ & enthalpy, $\mathrm{kJ} \cdot \mathrm{kg}^{-1}$ \\
\hline $\mathrm{N}$ & compressor \\
\hline$Q_{m}$ & $\begin{array}{l}\text { mass flowrate of air, } \\
\mathrm{kg} \cdot \mathrm{h}^{-1}\end{array}$ \\
\hline$Q_{v}$ & $\begin{array}{l}\text { volume flowrate, } \\
\mathrm{m}^{3} \cdot \mathrm{h}^{-1}\end{array}$ \\
\hline$r h$ & relative humidity \\
\hline & specific moisture \\
\hline SMER & $\begin{array}{l}\text { extraction rate, } \\
\mathrm{kg} / \mathrm{kW} \cdot \mathrm{h}\end{array}$ \\
\hline V & expansion valve \\
\hline$V_{d}$ & $\begin{array}{l}\text { theoretical dis- } \\
\text { placement of com- } \\
\text { pressor, } \mathrm{m}^{3} \cdot \mathrm{h}^{-1}\end{array}$ \\
\hline$W_{i}$ & $\begin{array}{l}\text { work delivered to } \\
\text { vapor refrigerant by } \\
\text { compressor, } \mathrm{kW}\end{array}$ \\
\hline$W_{c}$ & $\begin{array}{l}\text { power input to mo- } \\
\text { tor, } \mathrm{kW}\end{array}$ \\
\hline
\end{tabular}

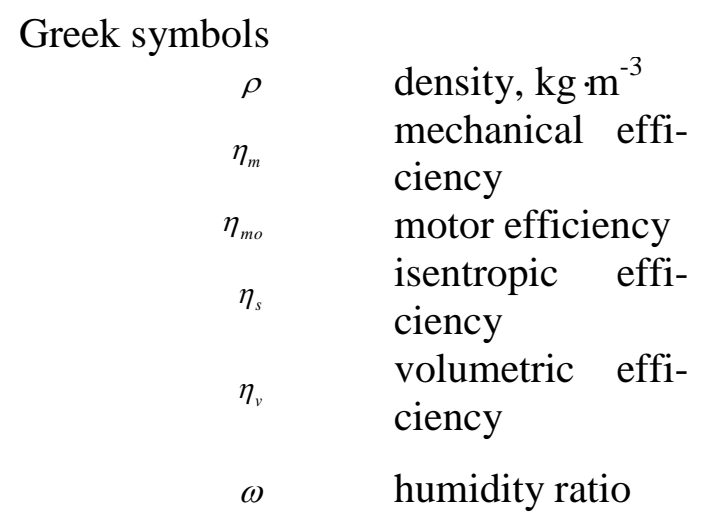

Subscripts

$\begin{array}{cl}\text { add } & \text { bypassed air flow } \\ \text { c } & \text { condenser } \\ \text { e } & \text { evaporator } \\ \text { r } & \text { refrigerant } \\ & \\ \text { water } & \text { water }\end{array}$

$1, \ldots, 12$

points in Fig. 1 or

Fig. 2

\section{References}

[1] Di, K. and J. Li, New technology and equipment of energy saving and emission reduction on grain drying system in China. Cereal \& Feed Industry, 2011.

[2] Chua, K., et al., Batch drying of banana pieces - effect of stepwise change in drying air temperature on drying kinetics and product colour. Food Research International, 2001. 34(8): p. 721-731.

[3] Kun, D.I., et al., Approaches to energy saving in grain drying process. Drying Technology \& Equipment, 2005.

[4] Colak, N. and A. Hepbasli, A review of heat pump drying: Part 1-Systems, models and studies. Energy Conversion and Management, 2009. 50(9): p. 2180-2186.

[5] Colak, N. and A. Hepbasli, A review of heat-pump drying (HPD): Part 2-Applications and performance assessments. Energy Conversion and Management, 2009. 50(9): p. 2187-2199.

[6] Perera, C.O. and M.S. Rahman, Heat pump dehumidifier drying of food. Trends in Food Science \& Technology, 1997. 8(3): p. 75-79.

[7] Claussen, I., et al., Atmospheric freeze drying-A review. Drying Technology, 2007. 25(6): p. 947-957. 
[8] Strommen, I., et al. Low temperature drying with heat pumps new generations of high quality dried products. in 13th International drying symposium. 2002.

[9] Klein, S. and F. Alvarado, Engineering equation solver. F-Chart Software, Madison, WI, 2002. 